In response to an appeal from the Admiralty, the Royal Astronomical Society is now sending round a circular to representative astronomers and societies in our own, the Allied, and neutral countries. This, after a brief résumé of the circumstances, enumerates the changes in the almanac that would be involved if the new system were adopted, and invites suggestions and criticism. It is thought that 1925 is the earliest date that is practicable for making the change, since the almanac goes to press several years in advance. It is proposed that the reckoning by Julian days shall still begin at Greenwich noon, in consequence of the numerous ephemerides of variable stars that have been drawn up on this system; this would afford a means of relief to those astronomers who dislike the change; by dating their observations in Julian days, instead of calendar dates, they could continue to keep their nights undivided.

It is hoped that the change, if made will be adopted throughout the astronomical world, so that an interval is wisely being left for full ventilation of the subject. Some have hopes that the change might be accompanied by the introduction of twenty-four-hour reckoning by the general public; this system has long been in use in Italy, and leads to a great simplification of time-tables of railways, tides, etc. It does not necessarily involve the use of new clocks with twenty-fourhour dials. It suffices to use the present dials, merely inserting $i 3^{h}$. to oh. inside the figures Ih. to $12 \mathrm{~h}$. In fact, many prefer this system since the hours on a twenty-four-hour dial are incunveniently close.

A. C. D. Crommelin.

\section{THE RECOVERY OF POTASH FROM BLAST-FURNACE GASES} $\mathrm{HE}$ sources of potash were described by Sir
Edward Thorpe in an article in NATURE of January 3 (p. 344). One of these sources has been the subject of study by Prof. R. A. Berry and Mr. D. W. McArthur, who have published the results of their investigations in a paper read before, and discussed at, a meeting of the West of Scotland Iron and Steel Institute. These investigators have studied in particular the possibilities of recovering potash from the blastfurnace gases obtained in Scottish practice, with the view of obtaining information as to how far these may be expected to constitute an economic source of supply, when the restrictions imposed by the war no longer hold.

That the dust deposited from blast-furnace and kiln gases contains potash salts has loth been known, and in 1884 Barclay and Simpson, of the Harrington Ironworks, Cumberland, took out a patent for the recovery of salts, and especially potash salts, from coke-fed furnaces. The most considerable investigation, however, on this subject is that by Wysor, of the Bethlehem Steel Company, U.S.A., who found that the dust which ccllected at the bottom of the stone chequer-work in the stoves and gas-fired boilers contained 15 per cent. of water-soluble potash $\left(\mathrm{K}_{2} \mathrm{O}\right)$. FurNO. 2530 , VOL. IOI] ther. he drew up a balance sheet to show the amoun $_{\mathrm{t}}$ of potash charged into the furnace and the percentage recovered. His conclusion was that the greatest losses occurred in the primary and secondary washers, constituting some 56 per cent. of the whole, while 20 per cent. was carried off in the slag; further, that less than $\mathbf{r}$ per cent. of the potash charged was recovered in the dust alluded to. In r9I6 a Cottrell plant for electrustatic precipitation was installed, and it was found that practically all the dust could be precipitated. About $22^{\circ} \mathrm{lb}$. of potash were charged per ton of pig-iron produced, and after deducting the amount contained in the slag and the dust-catcher, about $\mathrm{r}_{5} \mathrm{lb}$. per ton of pig-iron appeared to be left in the gases, which were then recoverable in the Cottrell plant.

The average potash content of the American ores is about I per cent., and as the production of iron in the United States in 1916 was nearly forty million tous, if Wysor's figures are correct the flue-uist from the furnaces should constitute ? very considerable source of supply.

As the authors point out, the problem in Scot land is different : first, because coal, and not coke is the fuel generally used, and secondly, because the ores contain rather less potash. With coke-fired furnaces the gases are not washed, but are led from the catchers direct to the stoves and boilers. In coal-fired furnaces, however, a considerable amount of tarry matter is produced, whereas the dust deposited is relatively very small. The problem of recovery is therefore different. The potassium is present in the ore, principally, no doubt, in the form of silicate. This reacts at the high temperature of the furnace and forms other compounds; for, as the dust analyses show. chlorides, sulphates, and carbonates were the principal acid radicals present. It is well known, further, that potassium cyanide is formed in certain regions of the furnace, but decomposed in others. . At the high temperature these potassium salts are vaporised; they condense in the cooler parts of the furnace as fine dust particles, and are carried along with the dust from the fuel and the ores. The first particles deposited are the heaviest, and these are caught in the dust-catcher, in the form of a coarse, black powder; deposition also occurs on the main tube, and these two constitute the tube cleanings. The heavy, tarry matter separates prineipally. in the condensers and carries with it much of the fine dust; the gas then passes to the water scrubbers, which retain the rest of the tarry matter and most of the remaining dust. Any mineral matter still retained is caught in the stove and boilers.

The authors have received and analysed samples of these deposits and liquors from various plants in Scotland, and have determined their potash content. Nine samples of flue-dusts were examined: eight from coal-fired furnaces and one from a coke-fired furnace. The highest yield of dust in the former was only at the rate of 21 tons per annum, as against 300 tons for the latter, and the water-soluble potash averaged 8.86 per cent. The percentage of ash in the tube cleanings varied 
from 53 to 74 per cent., but these contained a very small percentage of water-soluble potash, the highest being $2 \cdot 7$ per cent. Special attention was paid to the spent liquor, of which the specific gravity, total solids, ash, and water-soluble potash were determined; and the authors discuss various meihods of separating the mineral values from the tarry matter, which greatly hinders evaporation.

In the case of one firm the authors have drawn up a balance sheet showing the amounts of potash in the raw materials charged, and its distribution in the products. In one case where $7^{\div} 61 \mathrm{~b}$. were charged per ton of pig-iron, $6.04 \mathrm{lb}$. per ton were accounted for, of which $\mathrm{I}_{4} \mathrm{lb}$. were contained in the spent llyuor, $x_{7} \mathrm{lb}$. in the pitch, $0_{2} 2 \mathrm{lb}$. in the tube cleanings, $0^{\circ} 04 \mathrm{lb}$. in the flue- and stove-dust, and $2^{\circ} 7 \mathrm{lb}$. in the slag, leaving $\mathrm{I}^{\circ} 6 \mathrm{lb}$. unaccounted for. This balance sheet is very different from that obtained by Wysor, but too much stress should not be laid upon it, because the figures refer to one plant only. The authors estimate finally that about 1667 tons of water-soluble potash are recoverable per annum from the Io2 Scotch furnaces. They give, however, no estimate of the total amount of insoluble potash, and refer only briefly to the possibility: of its being rendered soluble. It does not look as though the prospect of recovering potash profitably in Scotland after the war was at all promising, and this view was emphasised in the discussion which followed.

\section{H. C. H. C.}

\section{WAR-TIME RESEARCH IN THE UNITED STATES.}

$\mathrm{IT}^{\mathrm{T}}$ is difficult to find in this country in these days a scientific worker, however recondite his studies may have been in pre-war days, who is not engaged in problems connected with the war, the development of industry, or the extension of trade. A similar state of things, at an earlier stage, is to be seen-in the United States, where the National Academy of Sciences has formed a National Research Council, which is organising research on current problems. The council is nothing if not catholic in its ideas of war-time research, and the subjects allocated to its committees and sub-committees range from palæontology to psychology.

The council has apparently been much concerned to secure for American libraries and scientific institutions supplies of German scientific literature, held up in Amsterdam and London as a result of the British blockade. The difficulty has been satisfactorily solved, and official forms have been duly evolved for the liberation of consignments, certified by the Library of Congress in Washington and the United States Consul in London.

The Geology and Palæontology Committee of the council has published a brochure entitled "What a Geologist can do in War." This has been 1 reely distributed among Army officers, with the view of explaining what service they can expect from geologists. The same committee is collect- ing inıormation as to the materials available in the coastal States for the construction of roads and fortifications.

In association with other organisations the Committee on War Minerals has made a census of all minerals required for war purposes, with notes on their production, stocks held in the United States, sources of supply, and other matters. Special surveys have been undertaken in sume cases to complete information regarding minerals and to secure data necessary to permit of the rapid exploitation of deposits.' Dr. Dean, curator of the Department of Arms and Armour in the Metropolitan Museum and of Fossil Fishes in the American Museum, and a member of this committee, has designed models for modern body armour, which are now being made for trial in field operations.

The Committee on Zoology has organised an extensive field of work in connection with the elimination and control of animal pests, esperially those known to be carriers of disease, the examination of pathological specimens, investigation of water and soils from camp-sites, and the disposal of garbage and drainage. Even more important. perhaps, in view of the urgency of the food problems caused by the war, is the work this committee intends to undertake on the improvement of breeds of domestic animals, better methods of increasing and conserving stock, and possible remedial measures against food-destroying insects. Another interesting problem in its programme : s the study of limbs and joints with the view of improving the construction of artificial limbs. The utilisation of aquatic birds in locating submarines, a subject which has not escaped the attention of the popular Press in this country: is also being considered.

The programme of the Botanical Raw Products Committee is perhaps the most far-reaching of all, since it aims at establishing for the use of manufacturers a kind of "clearing house of information" regarding raw materials, exclusive of food staples. This committee proposes to collect all available information regarding plants of economic value with the view, among other things, of producing supplies of essential raw materials at home, providing substitutes for materials previously imported, and investigating the possibilities of new raw materials. This committee points out that "often a great industry buys its raw material from a broker or an importing house without knowledge of either the geographic or the specific source. When this source is cut off, as has frequently been the case during the past three years, and as possibly will be more frequent during the next few years, the manufacturer has been placed in an uncomfortable position. Curiously enough, such a predicament is many times brought about by the curtailment of a product used in such relatively small quantities that the fact that it is essential to the finished article is overlooked or forgotten during times of plenty." This opinion is worth quoting, as it diagnoses accurately a predicament 